Sohini Ghosh ${ }^{1}$

JEL: M00

Sraboni Dutta ${ }^{2}$

DOI: $10.5937 /$ industrija1-9798

UDC: 005.591 .45

Scientific review

\title{
Mergers and Acquisitions: A Comparative Review of Literature
}

\author{
Article history: \\ Received:18 December 2015 \\ Sent for revision:22 December 2015 \\ Received in revised form: 4 February 2016 \\ Accepted: 17 February 2016 \\ Available online: 1 April 2016
}

\begin{abstract}
The paper aims to review scholastic research on the effect of M\&As on firm performance and present a comparative analysis of Indian M\&As visa-vis those occurring in other nations. 108 articles in referred journals published between 2005 and 2015 have been surveyed with a focus on comparing firm performance parameters prior and post the M\&A. Firm performance has been inspected via three measures i.e. accounting measures, stock market performance measures and qualitative measures. On the basis of these three measures, literature on mergers in India with those occurring in another 23 countries was compared. The review has shown that irrespective of the nation, M\&As may impact the accounting and stock market performance measures of the acquirer and target firms in a positive, negative or mixed manner. M\&As in nations other than India have received more academic attention with respect to the effect on qualitative issues like cultural compatibility, downsizing and innovation. Cultural incompatibility and downsizing are problems of M\&As in India as well as other nations. Indian domestic M\&As have resulted in greater market share whereas majority of the M\&As in other nations have lost customer base. Although literature studying the outcomes of M\&As on firm performance from a pre-post perspective are multifarious, a comparative assessment of the studies on M\&As occurring in India with those carried out in other nations of the world is a novel attempt.
\end{abstract}

Keywords: Mergers and Acquisitions, Profitability, Shareholders' Wealth, Downsizing, Cultural Compatibility, Innovation, Market Growth

\footnotetext{
${ }^{1}$ Birla Institute of Technology, Mesra, Kolkata Extension Centre, India 2 Birla Institute of Technology, Mesra, Kolkata Extension Centre, India, sdutta@bitmesra.ac.in
} 


\section{Spajanje i preuzimanje firmi: uporedni pregled literature}

Apstrakt: Cilj ovog rada je pregled sholastičkih istraživanja o uticaju spajanja i preuzimanja na rezultate kompanija $i$ predstavljanje uporedne analize spajanja i preuzimanja firmi u Indiji u odnosu na druge zemlje. Pregledano je 108 članaka iz časopisa objavljenih između 2005. i 2015. godine sa fokusom na poređenje parametara učinka kompanija pre $i$ posle spajanja $i$ preuzimanja. Učinak kompanije se proverava upotrebom tri mere tj. računovodstvenih mera, mera performansi berze i kvalitativnih mera. $\mathrm{Na}$ osnovu ove tri mere, izvršeno je poređenje literature o spajanju i preuzimanju firmi u Indiji i još 23 zemlje. Pregled je pokazao da bez obzira na naciju, spajanje i preuzimanje firmi može imati pozitivan, negativan ili kombinovan uticaj na mere performansi računovodstva i berze kod sticaoca i ciljanih firmi. Spajanje i preuzimanje firmi u zemljama osim Indije dobijaju više akademske pažnje u pogledu uticaja kvalitativnih pitanja kao što su kulturna kompatibilnost, smanjenje radne snage $i$ inovacije. Problemi spajanja $i$ preuzimanja firmi $u$ Indiji kao $i$ u drugim zemljama su kulturna nekompatibilnost i smanjenje radne snage. Spajanje i preuzimanje indijskih domaćih firmi doveli su do većeg učešća na tržištu, dok je većina spojenih $i$ preuzetih kompanija u drugim zemljama izgubila bazu kupaca. Pored raznovrsne literature koja proučava uticaj spajanja i preuzimanja na učinke firmi pre i posle ovakvih transakcija, komparativna procena studija o spajanju $i$ preuzimanju firmi u Indiji i onih u drugim zemljama sveta predstavlja novinu na ovom polju.

Ključne reči: spajanje i preuzimanje firmi, profitabilnost, akcionarska imovina, smanjivanje radne snage, kulturna kompatibilnost, inovacije, rast tržišta

\section{Introduction}

In the dynamic business scenario, Mergers and Acquisitions (M\&A) is one of the best processes of corporate restructuring that has gained substantial prominence in both developed and developing nations. Reviewing published literature in the area of M\&As gives a deeper insight on whether empirically it can be supported that M\&As are useful tools of corporate restructuring. Studies of post-merger performance usually follow one of the two general approaches of share-price movement analysis or analysis of operating performance to see the merger-related gains. However qualitative issues such as effect on employees, innovation and competitive advantage have also gained academic attention. Inspired by the paper by Ismail et. al. (2011), in this compendium, we have focused on literature on consequences of M\&As on firm performance from a pre-post perspective. The firms' performance in the post M\&A phase has been examined via three measures of study, i.e. 
accounting measures, stock market performance measures and qualitative measures. On the basis of these three above mentioned measures, our study presents a comparison of the literature on mergers in India with those pertaining to other countries. Although there are various literature studying the consequences of M\&As on firm performance from a pre-post perception, a comparative evaluation of the studies on M\&As occurring in India with those carried out in other realms of the world is a unique attempt.

The review of the literature spans countries such as India, Pakistan, Sri Lanka, Philippines, Malaysia, China, Japan, Hong Kong, Turkey, Singapore, South Korea, Taiwan, Egypt, Poland, Lithuania, Vietnam, USA, Canada, Europe, Netherlands, Australia, New Zealand etc. We have focused on the journals that have been published in the period between 2005 till 2015.

\section{Studies on Accounting Measures of Performance}

The operating performance approach compares the performance of companies between the pre-merger and post-merger phase by using accounting data which determines whether consolidation leads to changes in reported costs, revenue or profit figures. The most widely researched financial parameters in relation to M\&A are profitability, productivity, $\mathrm{ROI}$, market share etc. Review of literature shows that the impact of M\&As on the operating performance and profitability of firms may be both positive or detrimental in nature. This section first discusses the studies dealing with mergers in nations other than India followed by studies undertaken on Indian mergers.

Feroz et al. (2005) analyzed the effect of mergers on the financial performance of US firms and pointed out that managerial efficiency of $82 \%$ of the sampled firms improved in the post-merger periods. Walter and Uche (2005); Uchendu (2005); and Kama (2007) enlightened us on the post M\&A performances of banks in different countries of the world. The operating performance showed improvement in banks of Nigeria, Malaysia and Chile. The investigation of US construction firms by Choi and Harmatuck (2006) revealed that operating performance reported slight improvement in the longrun although the results were statistically insignificant. Considering parameters such as profitability, cash flow, efficiency, leverage and growth for a sample of 72 Australian mergers, Lau et al. (2008) compared the operating performance of merged firms with that of the targets and acquirers in the premerger phase. The results showed that mergers improved the post-merger operating performance. Joshua (2011) was also of the view that post M\&A performance of banks was financially efficient. Olalekan and Adebayo (2012) were of the opinion that M\&As in Nigerian banks had improved the overall performance of banks and contributed immensely to the growth. 
The following studies revealed that the event of M\&A failed to escalate the performances of the firms in the post-merger phase. By deploying ratio analysis, Kemal (2011) examined the post-merger financial performance of Royal Bank of Scotland in Pakistan for the years 2006-2009 and found that profitability, liquidity, assets, leverage, and cash flow positions of RBS was better in the pre-merger phase compared to the post-merger one. The post M\&A performance in US banks was negative. (DeLong and Deyoung (2007). The study of M\&As in the pharmaceutical industry by Demirbag et. al. (2007) pointed out that there was no value creation in terms of ROI and profit margin. Majumdar et al. (2007) scrutinized the effects of mergers on the financial performance and efficiency level of US telecom firms to find that cash flows decreased in the post-merger stage. The impact on efficiency and synergy was also negative. Oduro and Agyei (2013) conducted an accounting based study of M\&As of firms listed in the Ghana Stock Exchange. They proved that there were significant differences in profitability in the pre and post-merger period and the phenomenon affected profitability of the firms negatively. The research also pointed out that level of risk and firm size had significant negative relationship with firm profitability while debt capital and firm growth enhance firm profitability. Marfo et. al. (2013) studied accounting based effects of M\&As on the performance of firms in the Ghana Stock Exchange from 1999 to 2010 by using t-test and panel data analysis. The study revealed that M\&As have a significant negative impact on the profitability of businesses.

The studies in this section report that M\&A had a mixed impact on the performance of the firms. Cabanda and Pascual (2007) evaluated the financial and operating performances of shipping companies in Phillipines undergoing mergers. While acid test ratio, total asset turnover and net revenues improved significantly in the long run, net income, return on asset, return on sales, net profit margin, capital expenditure, capital expenditure to sales, and capital expenditure to total asset did not show significant gains after merger in the short run. By investigating the long-term profitability of corporate takeovers in Europe, it was found that both acquiring and target companies significantly outperformed their peers in the industry but the profitability of the combined firm decreased significantly post takeover. (Martynova et. al. (2007)). Ismail et al. (2010) observed post-merger operating performance of Egyptian companies in construction and technology sectors and found that while M\&As have played a positive role in improving profitability in the construction sector, it failed in the technology sector. However, M\&As did not improve efficiency, liquidity, solvency and cash flow positions in both sectors. Although many researchers across the world have addressed the question of whether M\&As improve the operating performance of firms, from the review we find that there is no consensus on this issue. 
Numerous Indian studies on M\&As focused on operating performance and profitability of the firms in the post-merger phase. Vanitha and Selvan (2007) and Indhumati (2011) compared the performances of the acquirer and target corporate firms in India during the pre and post-merger periods. They found that the financial performances of acquiring firms were better than that of target firms. Mantravadi and Reddy (2008) noticed that particularly M\&As in the Indian banking and finance sector had a slightly positive impact on profitability. Kar and Soni (2010) examined the impact of M\&As on performance of Indian corporate enterprises in the post liberalisation period from 1990-91 to 2000-01. They indicated that turnover of the companies increased after the M\&A. Profit after tax and book value of the companies increased post M\&As during 1994-98 and 1994-99 respectively. Further, M\&As did not have any impact on return on net worth (RONW) for the period of study. In the Indian manufacturing sector, the overall efficiency of the acquirer firms increased due to improvement in profitability, liquidity, operating performance and financial and operating risk positions of the companies (Azhagaiah and Kumar 2011). Khan (2011) used independent t-test and compared pre and post-merger financial performance of merged banks via financial parameters like gross profit margin, net profit margin, operating profit margin, return on capital employed (ROCE), return on equity (ROE) and debt equity ratio and also the overall impact of M\&As on acquiring banks to find that the acquiring banks had been positively affected by the event of M\&A.

The following studies revealed that the event of M\&A failed to reap any benefits for the firms in the post-merger phase. Tambi (2005) attempted to evaluate the impact of mergers in Indian corporations on PBITDA, PAT and ROCE for any change, by using t-test. The results of his study specified that mergers failed to contribute positively in the set of companies chosen by him. Kumar (2009) examined the post-merger operating performance of acquiring companies involved in merger activities during the period 1999-2002 in India. It was found that the post-merger profitability, assets turnover and solvency of the acquiring companies, on an average, showed no improvement when compared with pre-merger values. Mahesh and Prasad (2012) examined the mergers in the Indian airline companies and concluded that there was no improvement in the return on equity (ROE), net profit margin and interest coverage post M\&A. Kalra et. al. (2013) probed whether Indian banks realized performance competence during the post-merger period in the fields of profitability and liquidity and pointed out that there was no significant impact on financial performance of the banks. A pre-post comparative analysis of the profitability and liquidity positions of Indian commercial banks by Chellasamy and Ponsabariraj (2014) showed no improvement in the post-merger period compared to the pre-merger one. Daddikar and Shaikh (2014) carried out a pre-post comparative analysis of the financial performance of Jet Airways. 
They concluded that there was no enhancement in the ROE, net profit margin, and interest coverage in the post M\&A period.

The fact that M\&As had mixed influence on the performances of Indian firms was proved by the following studies. Malhotra and Zhu (2006) conducted a research on post-acquisition financial performance of Indian firms engaged in acquisition of US firms. They studied the post-acquisition impact on the financial performance of the acquiring firms. Results showed that with respect to long-term announcement, Indian international acquisitions underperformed. Net sales to growth and foreign export sales increased after the acquisition while other financial ratios decreased post acquisition. Srivassan et al. (2009) expressed his observations on financial implications and problem occurring in M\&A. He highlighted that mergers increased the firm size but there was no guarantee of maximizing profitability on a sustained business. The study by Sinha and Gupta (2011) examined the M\&A in the Indian financial services sector to find while profitability was positively affected postmerger, the liquidity condition had deteriorated. It also indicated the positive effects on earnings before interest and tax (EBIT), profit margin, interest coverage and cost efficiency. Kumara and Satyanarayana (2013) compared the pre and post M\&A performance of 10 major merger deals in India to find a significant positive value creation and improved liquidity positions for the acquired firms. Return on capital employed (ROCE), return on long term funds, and return on assets (ROA) increased positively but return on net worth (RONW) declined. However, the results were not statistically significant. Khurana and Warne (2014) studied the impact of cross border M\&As of five Tata group companies. They interpreted that M\&As positively affected the profitability and liquidity statuses of Tata Communication and Tata Power. However, the earnings decreased in Tata Motors, Tata Steel and Tata Chemicals in the post-acquisition phase compared to the pre-acquisition period.

\section{Studies on Stock Market Performance Measures}

The main aspect of these studies is using stock market measures to examine the consequence of M\&As on the financial performance. The phenomenon of a M\&A deal is said to be successful if it results in value creation for the shareholders of the firms. Yuce and $\mathrm{Ng}$ (2005) probed the consequence of mergers announcements of Canadian firms on the abnormal returns and indicated that both the target and the acquiring company shareholders earn significant positive abnormal returns. Capron and Shen (2005) tried to explore the dissimilarities in the acquisitions of public versus private organisations. They opined that in general, acquirer returns were positive when private firms were bought. Kling (2006) explored the success of the mergers wave in 
Germany for the period ranging from 1898 to 1904 and reported that mergers affected stock returns positively in all industries except for banks. Studies conducted by Hassan et. al (2007) and Mehrotra et. al. (2008) pointed out that M\&A had a positive impact on the shareholder wealth creation in US based pharmacy companies. Khanal et. al. (2014) studied the impact of M\&As on stock prices and value of publicly traded firms in the ethanol based biofuel industry in the US between 2010 and 2012. Results suggested that the market responded positively toward M\&As in the industry with respect to average CAAR of acquiring firms. Selcuk and Kiymaz (2013) explored the influence of diversifying acquisitions on acquiring Turkish organisations during 2000-2011. They found that acquiring enterprises underwent statistically significant abnormal returns. By using cross-sectional regression, they concluded that diversifying acquisitions created higher abnormal returns to acquirers compared with focused acquisitions.

M\&As has spelled doom for the performances of the firms in the post M\&A period was proved by the following studies. By comparing the price paid by foreign corporates for acquisitions in the US with the price paid by US firms for domestic acquisitions, it was noticed by Post (2006) that foreign firms pay more and the results yield significantly lower returns on M\&A investments. The value of the combined firm rose, sometimes, but there was no significant improvement in the acquirer's operating performance. (Bhagat et al (2005), Betton et al. (2008), Bradley and Sundaram (2006), Moeller et al. (2007); Savor and Lu (2009), Moeller and Sehlingemam (2005)). Wang (2012) opined that the phenomenon seemed to benefit targets but did not create value for acquirers. Stunda's (2014) study in the US compared effect on stock price of acquiring firms with that of firms which were not involved in M\&As. The nonM\&A firms yielded significantly positive effect on stock price whereas the acquiring firms experienced significantly negative effect on the stock price. He proved that excepting oil and gas industry and banking and financial services industry, the event of M\&As deployed a significant negative impact on stock prices.

The studies discussed below throw light on the fact that M\&As led to a mixed outcome in the performances of the organisations post-merger. Campa and Hernando (2005) shed light on the relationship between merger announcements and shareholders' wealth in the European financial industry. According to them, mergers announcements brought positive excess returns to the shareholders of the target company whereas there were zero returns to the shareholders of acquiring firms in European financial industries. Studies by Vaziri (2011); Knapp et al. (2006) and Koetter et al. (2007); Hernando, Nieto and Wall (2009); Vergos and Christopoulos (2008) have shown that there was long term gain in value for acquirer bank companies but on a short term basis, mixed results were observed. Wong et. al. (2009) explored the impact of acquisition declarations on the pricing actions of the bidding and 
target organisations from Hong Kong, China, Taiwan, Singapore, South Korea and Japan over the time 2000-2007. Their research confirmed that information regarding an approaching corporate takeover was judged as good news for the shareholders of bidding firms and not for the shareholders of the target firms. They also pointed out that the abnormal return for the shareholders of bidding firms during the post-announcement period depended on the type of acquisition. Branch et. al. (2012) investigated under what conditions a broadly diversified investor, with stake in both bidder and target, got rewarded or was adversely affected by a proposed acquisition. They deciphered that large takeovers produced considerable advantages for shareholders and bondholders of target companies. Shareholders of bidding firms and the bondholders reaped no gains. Boubaker and Hamza (2014) investigated the short and long term stock returns positions of acquiring financial firms of UK over the period 1996-2007 and also the association between short-term abnormal return and the long-term performance. The event study method pointed out that the wealth of the bidders encountered significant decline in the short-term. On the contrary, both the buy-and-hold abnormal returns and bidder's portfolio return was positive and noteworthy in the long run.

The effect of M\&A on stock market positions of firms were studied in India as well. Malhotra and Zhu (2006) conducted a research on post-acquisition financial performance of Indian firms engaged in acquisition of US firms. The study revealed that domestic market had significant positive response to the short-term announcement. Anand and Singh (2008) studied the effects of mergers in the Indian banking sector on the shareholders' wealth. Results indicated that merger announcements had been positive and significant for both bidder and target banks. Kumar and Panneerselvam (2009) who presented a comparative study of the effect of M\&A on the wealth of shareholders of acquirer and target firms during the period 1998-2006, indicated that M\&A activities had a positive effect on net present value for bidding and target firms. Sinha et. al. (2010) was of the opinion that the acquiring firms in the financial sector of India were able to generate value in the long run. Rani et. al.(2011) compared domestic to cross-border M\&As in Indian pharmaceutical industry and concluded that abnormal returns are highest in case of foreign based acquisitions and negative for India based mergers. Ramakrishnan (2012) tried to explore the strategic factors that affect the long-term post-merger performance of firms in India and concluded that the shareholders of the acquired firms enjoyed significant positive share price returns. Mallikarjunappa and Nayak (2013) reviewed the influence of takeover announcements in India on the stock price performance of target companies during 1998-2007. They concluded that target company shareholders enjoyed extensive and statistically significant CAAR and the chief gain from M\&As accrue to target company shareholders. Kalra et. al. (2013) used the standard 
event study approach to probe the changes in shareholder wealth and share price volatility of Indian banks during the post-merger period. The study revealed that there were significant improvement in EPS and the ratio of market value to book value of equity proving that the Indian stock market was efficient in the long-run. Khurana and Warne (2014) studied the impact of cross border M\&As of five Tata group companies on shareholders' wealth and profitability of the acquirer corporations during 2007-08. The effect on shareholders' wealth was found to improve in case of Tata-Teleservices and Tata Power. EPS of the Indian acquirer banks improved in the post-merger period (Ghosh and Dutta (2015)).

The following studies reveal that the event of M\&A has failed to perk up the performances of the Indian firms in the post-merger phase. Sony et al., (2009) were of the view that valuation of banks and fixation of swap ratio are significant factors from shareholders' viewpoint. In case of voluntary amalgamation in the Indian Banking Sector, they found that in majority of the cases the final swap ratio did not justify the financials of the merging banks. The study by Mahesh and Prasad (2012) confirmed that there was no enhancement in the EPS and dividend per share post M\&A in the Indian airline companies during the post liberalization period. Daddikar and Shaikh (2014) carried out a pre-post comparative analysis of the financial performance of Jet Airways after the consolidation in the Indian Airline Sector during 2007-08. They concluded that that there was no enhancement in the EPS and dividend per share in the post M\&A period. The effects of M\&A on share price movements and change in EPS have been investigated by many research scholars. Ghosh and Dutta (2013) explored the impact of M\&As in the Indian IT sector and concluded that there were no significant changes in the EPS and closing price on BSE of the acquirer companies in the postmerger period. Ghosh and Dutta (2014) conducted a study on the effects of M\&As in the Indian Telecom Sector. Here also they arrived at the judgement that the event of M\&A failed to bring any significant change in the EPS of the acquirer companies in the post-merger period.

The following studies pointed out that M\&As have brought out a mixed impact on the performances of the firms in India. Kumar and Suhas (2010) opined that mergers created value for the acquirer banks but eroded shareholder wealth for target firms. Ramakrishnan (2010) who researched on the effect of announcements of mergers on shareholder wealth in the Indian context concluded that the acquired firms' shareholders enjoyed significant wealth gains whereas the acquiring firms' shareholders did not experience the same. Ravichandran et. al. (2010) by examining relation between return on shareholders's fund (ROSF) and CRAMEL-type variables for seven Indian bank mergers in the pre and post-merger phase and found that ROSF was negatively related to cost efficiency and interest cover but was positively related to ratio of advances to total assets. 


\section{Studies on Qualitative Performance Measures}

In addition to extensive study on the impact of M\&As on financial parameters, the outcome of such events on qualitative issues like effect on employees, innovation and competitive advantage have also gained academic attention. It is since the late 1980s, that research began to focus on the human dynamics and people management issues of M\&As (Cartwright and Cooper, 1990). Schraeder and Self (2003) are of the opinion that "HR can make or break the M\&As". The exploratory study of M\&A in Australia by Mcdonald et. al. (2005) found that there was an association between corporate and M\&A objectives and due diligence played an important role in achieving success of M\&A. Salame (2006) compared the pre and post M\&A phase to point out that neglect of HR issues led to failure of M\&As. It was suggested that the senior executives need to encourage the participation of HR teams and employees in M\&A process. Björkman and Søderberg (2006) carried out an exhaustive study of M\&As in financial services companies in the Nordic countries. The research led to the following conclusions- HR was not invited by the top management to play any key role in the post-merger integration process. The $\mathrm{HR}$ issues which posed serious problems to the management were cultural incompatibility and communication problems, insufficient due diligence, undiversifiable risk, loss of productivity, decrease in salary, downsizing, losing old customers and problem in labour demand. The findings by Shook and Roth (2011) also supported the previous study. They found that HR practitioners were not involved in planning decisions related to downsizings, mergers, and/or acquisition. So they suggested that these practitioners need to play a more active role during the planning stages to ensure that training and development support the financial goals of these change events.

The following studies emphasize how M\&As impact worker productivity and ownership changes. Siegel et. al. (2005) and Siegel and Simons (2008) analyzed the "differential effects" on worker productivity for different types of changes in ownership occurring in more than 19000 Swedish firms during the period of 1985 to 1998. Ownership changes led to increases in relative productivity. This effect was strongly witnessed in full acquisitions and unrelated acquisitions.

M\&A results in attenuation of existing employee resource. Mylonakis (2006) examined the impact of M\&A on employment and on the efficiency of human resources in some selected banks in European countries. It was observed that M\&As in European banks reduced employee size during the 1998-2003 period. In the empirical analysis of Swedish manufacturing firms, Siegel and Simons (2006) found that M\&A enhanced plant productivity, although they also resulted in the downsizing of businesses. Downsizing is a plaguing consequence of many M\&A deals. Hence care should be taken on retention of 
key employees as pointed out by the following study. Richey et. al. (2007) focused on retention of relationship marketing managers (RMM) of target companies in the post-acquisition phase via upholding of the implicit agreements that have influenced them to continue with the target organisations. This retention creates positive outcomes for the firm by enhancing the efficiency of subordinate employees. They concluded that employees were the chief success aspects that enabled the target firms to operate efficiently post acquisition and negligence towards employees would adversely affect productivity.

Meshing of two or more cultures leads to culture change. Unfortunately, in many M\&As, the issue of cultural compatibility is not raised until after the deal has been accomplished. This leads to "cultural indigestion and the eventual divesture of units that cannot become culturally integrated". (Schein, 1990). Cultural diversity, sound communication and employee mix of the two firms play a vital role in post amalgamation of two firms. Cultural differences between the merging firms were key elements affecting effectiveness of the integration process and consequently the success of M\&As. (Lodorfos and Boateng (2006); Mitleton (2006); Lin et. al. (2006)). M\&As would result in organizational gains if successful integration of cultures of the combining organizations and people would occur. (Pinto et. al., 2006). The study conducted by Saundersa et. al. (2009) in the "Global Hotel" chain, with headquarters in USA, pointed out that open communication and pre-merger cultural audit were important necessities for achieving a sound cultural integration in the post-merger phase. Mohibullah (2009) highlighted four main issues related to culture clashes after an M\&A deal. The issues identified by him were ambiguity and cultural problems within the merged entity, improper management of cultural integration and improper acculturation process among the merged organisations. He opined that the organisations prior to integration should develop a proper top-down communication network among employees, thus decreasing the ambiguities found among the employees during the integration process. Weber and Tarba (2012) analyzed crosscultural management during all stages of M\&A. They concluded that the high rate of M\&A failures in spite of the increasing activity of M\&A may be due to lack of harmonized activities during all stages of the mergers. Doseck (2012) discussed the aspects of organisational culture, human capital management and change management and identified best practices and challenges of HRM professionals during the integration phase of M\&As. Rottig et. al. (2014) examined the role of culture in M\&A. They provided an exhaustive analysis of the many related but distinct constructs involved in the process. According to them, the lack of connections made among constructs had limited the consolidation of contributions. Human factors are critical in determining merger outcomes. By studying the implementation strategies of 86 acquisitions, Zaheer et. al. (2013) established that integration and autonomy 
of managers of the targets need not conflict each other. When target offered synergy primarily through complementarity instead of similarity, both integration and autonomy could be achieved. Syazliana et. al. (2015) declared that corporate cultures integration was a critical factor in success and failure of M\&A exercises in Malaysia. They suggested that companies should assign the best human resources for implementing M\&A deals and early planning of the integration process must be emphasized.

The ensuing researches throw light on how employees' perceptions change in the post M\&A period. By studying the effect of M\&A on different stakeholders, Waddock and Graves (2006) opined that employee diversity was a possible source of strategic advantage for US companies in the post-merger phase. They also concluded that post-merger efficiency did not influence the management-union relationships, employee involvement and retirement benefits issues. No differences were observed between the acquiring and merged organisations regarding employee polices in the pre and post-merger period. They pointed out that the acquirer firms often inflict their policies on the merged firm, which eventually jeopardize organisational culture of the newly formed entity. In the paper titled, "A Corporate's Responsibility to Employees during a Merger: Organizational Virtue and Employee Loyalty", Chun (2009) discussed how employee views of the merged organisation varied because of their company background. He also elucidated how employees' emotional response to the merged organisation was affected by their poor perception of the organisational virtue. He suggested that perceptions of organisational empathy, warmth and meticulousness were strongly correlated with employee loyalty, perceived job security, satisfaction and emotional attachment. He also pointed out that employees from the acquiring companies had more negative feelings towards the merged organisations. The study of bank mergers in Sri Lanka by Wickramasinghea and Karunaratneb (2009) highlighted that employee insights about people management issues in M\&As were affected by the nature of the merger and that employees were less satisfied in collaborative mergers compared to extension mergers. They also found that age, gender and marital status of employees influenced their perceptions, with age emerging as the most determining factor. However, from an HR outlook, collaborative mergers were the most intricate mergers to be implemented. This was because the acquiring firm already had proficiency in the business operation and hence would try to consolidate the two firms to avoid redundancy and become more cost effective. The effects of M\&As on innovation and research and development (R\&D) are discussed in this section. Liu and Zhou (2008) used panel data analysis to investigate how innovation in Chinese high-tech industries was affected by international technology spillovers which occurred due to greenfield FDI, cross-border M\&As and trade. They pointed out that greenfield FDI in these Chinese high-technology industries was associated 
with both intra-industry and inter-industry spillovers while cross border M\&As only generated inter-industry spillovers. Phillips and Zhdanov (2012) successfully showed how an active acquisition market affected firms in the spheres of innovation R\&D. The evidence provided by them clearly pointed out that the R\&D responsiveness of firms increased with demand, competition, and industry M\&A activity. They also noticed that all of these effects were stronger for smaller firms than for larger firms.

How the nature of alliance and choices of partners are influenced by the event of M\&A are discussed here. Yang et. al. (2011) projected that learning and network embeddedness acted as drivers of partner acquisitions in U.S. computer industry. The nature of alliance learning (exploratory or exploitative) when complemented with the correct structure of network embeddedness, helps to gauge the firms' subsequent acquisition decisions. Rogan and Sorenson (2014) scrutinized the global advertising industry from 1995 to 2003 to examine how acquirers' choices of partners for M\&A are affected by existence of common clients and the manner in which these indirect ties influence the performance of the combined organisations. They found that with this existence of common clients the probability of being acquired rose but the performance of merged entities declined.

Influences of mergers on the customer base and market growth have been discussed here. Meyer and Tran (2006) discussed the various strategies of market penetration adopted by multinational enterprises for expanding global customer base in emerging economies. They reviewed the case of Carlsberg Breweries which gained entry in the emerging economies of Poland, Lithuania, Vietnam and China by acquisition of local enterprises. Richey et. al. (2008) commented that the exit of relationship marketing managers (RMMs) from the target organizations would lead to losing prime customers and the possibility that the managers, who quit, would prompt those customers directly to the competitor firms.

The consequent arguments shed light on the effects of mergers on the aspects like technology, quality and knowledge. Groff et al. (2007) used Data Envelopment Analysis to test whether there were changes in technical efficiency associated with hospital mergers in the U.S. during 1994-1995 with a sample of 500 hospitals. The results showed that improvements in technical efficiency were not detected in the first year post merger but it improved significantly in the second year post merger. The significance of the study by Chen and Li (2014) was that they assessed the outbound M\&As by Chinese firms in US. Through these cross border mergers, the Chinese firms were able to gain access to more advanced technology and better management approach offered by American firms. Deng and Yang (2015) applied resource dependence theory (RDT) to comparatively investigate major factors that determine the level of cross-border M\&As by emerging market firms (EMFs) in 
developed and developing markets. They found that cross-border M\&As by EMFs helped firms to gain access to better resources. While patents and knowledge assets in developed economies were the dominant resources prompting M\&As, in developing economies, it was natural resources. By studying hospital mergers in USA, Calvert and Maki (2014) opined that consolidation via mergers generated improvements for both patients and communities. Post-merger, value is created through cost efficiency, better access and improved quality.

Research related to qualitative perspectives of M\&As in India have been discussed in the subsequent section. Jayadev (2007) evaluated some critical issues of consolidation of Indian banking (1993 - 2007) and deduced that $90 \%$ of the banks have declared HR issues to be the most complex organizational issue in case of mergers. Through a quantitative and qualitative study of Vodafone's acquisition of Hutchinson in India, Rizvi (2011) found that the HR department played a vital role in human capital development during the integration stage of M\&As for enhancing post acquisition organisational performances. Bhaskar (2012) captured the criticality of HR getting involved during the M\&A process. He pointed out that the key to success was to get $\mathrm{HR}$ involved at an earlier stage of the process, rather than after the deal was over. Before the merger, the difficult issues involved analyzing employee compensation. According to him, the real challenge was analyzing facets such as culture, decision-making styles, performance differentiation and organisational values. He opined that HR must observe the target organisation in terms of all employee related subjects like skills, capabilities, rewards and benefits. In the post-merger phase, differences in culture were the major challenge.

The succeeding cases enlighten us on the effect of M\&As on customer base and market power. Bhaskar et. al., (2009) found that in India, banks faced the problem of losing old customers and failed to attract the new customers. This was because the acquiring firms mainly focused on the economies of scale, efficiency gain and did not address the need of proper communication and concern for employees. It was inferred that proactive communication, changes in organizational structure, and appropriate human resource integration would smoothen the journey towards successful integration. Saboo and Gopi (2009) found that M\&As in Indian acquirer firms resulted in greater market share in domestic firms and negative effects were observed on cross-border firms. M\&A result in an increase in market power through enhancement of market share and customer base. (Ramakrishnan (2012), Goyal and Joshi (2011), Kar and Soni (2010). Goyal and Joshi (2011), by studying mergers in Indian banking sector, provided insight on the benefits emerging out of 17 M\&A deals. The M\&As led to access to better infrastructure and greater market share through wider geographical spread of branch networks and larger customer base, especially in rural areas. 
Impact of M\&As on technology has been studied in India as well. Das and Kapil (2015) conducted an empirical research studying 372 Indian technology firms during 2001-2011 and analyzed the influence of firm-specific factors on M\&A decisions of the firms. Gaining access to and control of technology assets, play an important role in influencing acquisition decisions of high-tech firms in emerging economies. Their results showed that financially strong, low-debt firms with high market capitalization were the typical acquirers in this segment and they tend to be serial acquirer too.

\section{Conclusion}

The survey of literature has revealed that the studies conducted so far in the area of M\&As have primarily concentrated on different financial parameters, cross cultural integration process and problems in cross-border M\&As. India is at par with the rest of the world as far as research on different financial aspects of M\&As are concerned. It was deciphered from the review that the phenomenon of M\&A has positive, negative as well as mixed impact on the financial performances of the acquirer and target firms of India. The scenario is same in case of other nations of the world. The aspects gaining steady popularity but less traversed, are the qualitative issues revolving around M\&As. The developing nations have started concentrating on issues like due diligence study, cultural compatibility, downsizing, customer base, technology, $R \& D$ and quality. Of all the preceding issues mentioned, cultural compatibility of the merged firms emerges as the most studied area in the period of this study. Some studies on different qualitative issues such as involvement of HR in M\&A decision making and integration processes, problem of losing customer base, market share, impact of M\&As on technology have taken place in India. But when the variety of qualitative perceptions and number of studies on qualitative issues are concerned, India is still lagging behind the other countries of the world. This paper helps in understanding the impact of M\&As from different perspectives. We suggest that future studies should focus more on the impact of M\&As on qualitative issues. If qualitative issues are not given equal importance as their financial counterparts, the overall impact of M\&As on the performance of the firms cannot be completely captured. Thus we can conclude that this extensive survey of available literature contributes towards better understanding of the phenomenon of $M \& A$ and eventually facilitates in contemplating how research on M\&A activities can be more holistic. 


\section{Reference}

Anand, M., \& Singh, J. (2008). Impact of Merger Announcements on Shareholders' Wealth: Evidence from Indian Private Sector Banks. Journal for Decision Makers, 33(1), 35-54.

Azhagaiah, R., \& Kumar, T.S. (2011). Corporate Restructuring and Firms' Performance: An Empirical Analysis of Selected Firms Across Corporate Sectors in India. Interdisciplinary Journal of Research in Business, 1(4), 58-82.

Betton, S., \& et. al., (2008). Corporate Takeovers. (pp. 292-427). Elsevier. Ch 15.

Bhagat, S., \& et. al., (2005). Do Tender Offers Create Value?, New Methods And Evidence. Journal Of Financial Economics, 76, 3-60.

Bhaskar, A.U., \& et.al., (2009). Role of Communication and HR Integration: A Study of a Bank Merger. Retrieved from http://www.ileradirectory.org/15thworldcongress/files/papers/Track_1/Poster/CS1 W_13_BHASKAR.pdf 2014 Nov 23.

Bhaskar, A.U. (2012). HR As Business Partner During M\&As: The Key To Success Is To Get Involved Early. Human Resource Management International Digest, 20(2), 22-23.

Björkman, I., \& Søderberg, A.M. (2006). The HR Function In Large-Scale M\&As: The Case Study Of Nordea. Personnel Review, 35(6), 654-670.

Boubaker, S., \& Hamza, T. (2014). Short- And Long-Term Wealth Gains From UK Takeovers: The Case Of The Financial Industry. The Journal of Applied Business Research, 30(4), 1253-1262.

Bradley, M., \& Sundaram, A. (2006). Acquisition and Performance: A Reassessment of the Evidence. Working Paper, Duke University,

Branch, B., \& et. al., (2012). Mergers and Acquisitions and the Universal Investor. (pp. 1-28). Retrieved from http://www.irrcinstitute.org/pdf/Universal-OwnersResearch_January-2012.pdf 2014 Nov 23.

Cabanda, E., \& Pascual, M.P. (2007). Merger in the Philippines: Evidence in the Corporate Performance of William, Gothong, and Aboitiz (WG\&A) Shipping Companies. Journal of Business Case Studies, 3(4), 87-100.

Calvert, M.E.G., \& Maki, J.A. (2014). Hospital Realignment: Mergers Offer Significant Patient And Community Benefits, Center For Healthcare Economics And Policy. Retrieved from http://www.fticonsulting.com/ /media/Files/usfiles/insights/reports/hospital-realignment-mergers-offer-significant-patient-andcommunity-benefits.pdf 2015 Jan 27.

Campa, J.M., \& Hernando, I. (2005). M\&A Performance In The European Financial Industry. Working Paper, 9-41.

Capron, L., \& Shen, J.C. (2005). Acquisitions of Private versus Public Firms: Private Information, Target Selection and Acquirer Returns. Working Paper, 3-46.

Cartwright, S., \& Cooper, C.L. (1990). The Impact of Mergers and Acquisitions on People at Work: Existing Research and Issues. British Journal of Management, 1(2), 65-76. doi:10.1111/j.1467-8551.1990.tb00163.x

Chellasamy, P., \& Ponsabarira, N. (2014). Performance Evaluation Of Mergers And Acquisitions Of Scheduled Commercial Banks In India. Vidyaniketan Journal of Management and Research, 2(1), 39-49. 
Chen, S., \& Li, Z. (2014). China's Outbound Mergers And Acquisitions In The U. S.. Frontiers Of Law In China, 9(3), 465-489.

Choi, J., \& Harmatuck, D. (2006). Post-Operating Performance Of Construction Mergers And Acquisitions Of The United States Of America. Canadian Journal of Civil Engineering, 33, 266-277.

Chun, R. (2009). A Corporate's Responsibility To Employees During A Merger: Organizational Virtue And Employee Loyalty. Corporate Governance. The International Journal Of Business In Society, 9(4), 473-483.

Daddikar, P., \& Shaikh, A.R.H. (2014). Impact of Mergers and Acquisitions on Surviving Firm's Financial Performance: A Study of Jet Airways Ltd.. Pacific Business Review International, 6(8), 45-51.

Das, A., \& Kapil, S. (2015). Inorganic growth of technology sector firms in emerging markets: Influence of firm-specific factors in Indian firms' M\&A Activities. International Journal of Emerging Markets, 10(1), 52-72.

de Long, G., \& De Young, R. (2007). Learning by Observing: Information Spillovers in the Execution and Valuation of Commercial Bank Merger and Acquisitions. Journal of Finance, 62(1), 181-216.

Demirbag, M., \& et. al., (2007). Performance of Mergers and Acquisitions in the Pharmaceutical Industry: A Comparative Perspective. The Multinational Business Review, 15(2), 1-22.

Deng, P., \& Yang, M. (2015). Cross-Border Mergers And Acquisitions By Emerging Market Firms: A Comparative Investigation. International Business Review, 24(1), 157-172.

Doseck, K.E. (2012). A Phenomenological Study Of HRM Practitioner Merger And Acquisition Integration Preparation: Perspectives On Organizational Culture, Human Capital Management, And Change Management. (pp. 7-12). Capella University, ProQuest, UMI Dissertation Publishing.

Feroz, , \& et al., (2005). Performance Measurement in Corporate Governance: Do Mergers Improve Managerial Performance in the Post Merger Period. Review of Accounting and Finance, 4, 86-101.

Goyal, K.A., \& Joshi, V. (2011). Mergers in Banking Industry of India: Some Emerging Issues. Asian Journal of Business and Management Sciences, 1(2), 157-165.

Ghosh, S., \& Dutta, S. (2013). Impact of Mergers and Acquisitions in Indian IT SectorA Comparative Study. JIS Management Vista, 7(1), 29-47.

Ghosh, S., \& Dutta, S. (2014). Mergers and Acquisitions: A Strategic Tool for Restructuring in the Indian Telecom Sector. InProceedings of Procedia Economics and Finance. (pp. 396-409). Pune, India: Elsevier.

Ghosh, S., \& Dutta, S. (2015). Mergers and Acquisitions in Indian Banking Sector: PrePost Analysis of Performance Parameters. International Organization of Scientific Research in Journal of Business and Management (IOSRJBM), ), 17(3), 1-9. 1.

Groff, E., \& et. al., (2007). Measuring Efficiency Gains from Hospital Mergers. Research in Healthcare Financial Management, 1-10.

Hassan, M., \& et. al., (2007). Do Mergers And Acquisitions Create Shareholder Wealth In The Pharmaceutical Industry. International Journal of Pharmaceutical and Healthcare Marketing, 1(1), 58-78.

Ismail, T.H., \& et. al., (2010). Exploring Improvements of Post-Merger Corporate Performance: The Case of Egypt. The ICFAI University Journal of Business Strategy, 1, 89-104. 
Jayadev, M., \& Sensarma, R. (2007). Mergers In Indian Banking: An Analysis. (pp. 241). Bangalore: Indian Institute Of Management; Birmingham: Business School, University Of Birmingham.

Joshua, O. (2011). Comparative Analysis Of The Impact Of Mergers And Acquisitions On Financial Efficiency Of Banks In Nigeria. Journal Of Accounting And Taxation, 3(1), 1-7.

Kalra, A., \& et. al., (2013). Wave of Mergers and Acquisitions: Are Indian Banks Going Up a Blind Alley. Global Business Review, 14(2), 263-282.

Kama, U. (2007). Bank Post Consolidation, Issues and Challenges in Malaysia and India: Lessons of Experience. Bullion, Central Bank Of Nigeria, Abuja, 31(4), 3647.

Kar, R.B., \& Soni, A. (2010). Mergers And Acquisitions In India: A Strategic Impact Analysis For The Corporate Enterprises In The Post Liberalisation Period. Retrieved from http://www.igidr.ac.in/conf/money/mfc13/MERGERS\%20AND\%20ACQUISITION S\%20IN\%20INDIA.pdf 2012 Jan 1.

Kemal, M.U. (2011). Post-Merger Profitability: A Case of Royal Bank of Scotland (RBS). International Journal of Business and Social Science, 2(5), 57-162.

Khanal, A.R., \& et. al., (2014). Impact Of Mergers And Acquisitions On Stock Prices: The U. S. Ethanol-Based Biofuel Industry. Biomas and Bioenergy, 61, 138-145.

Khan, A.A. (2011). Merger And Acquisitions (M\&As) In The Indian Banking Sector In Post Liberalization Regime.International. Journal of Contemporary Business Studies, 2(11), 31-45.

Khurana, R., \& Warne, D.P. (2014). Mergers, Acquisitions and Firms' Performance: Experience of TATA Industry.International Journal of Entrepreneurship and Small Business Management, 1(1), 33-50.

Kling, G. (2006). The Long-Term Impact Of Mergers And The Emergence Of A Merger Wave In Pre-World-War I Germany.Explorations in Economic History, 43(4), 667-688.

Kumara, N.V., \& Satyanarayana, M. (2013). Comparative Study Of Pre And Post Corporate Integration Through Mergers And Acquisition. International Journal of Business and Management Invention, 2(3), 31-38.

Kumar, B.R., \& Panneerselvam, S. (2009). Mergers, Acquisitions And Wealth Creation: A Comparative Study In The Indian Context. IIMB Management Review, 21(3), 222-242.

Kumar, B., \& Suhas, K.M. (2010). An analytical study on value creation in Indian bank mergers. Afro-Asian J. of Finance and Accounting, 2(2), 107. doi:10.1504/AAJFA.2010.037281

Kumar, R. (2009). Post-Merger Corporate Performance: An Indian Perspective. Management Research News, 32(2), 145-157.

Lau, B., \& et. al., (2008). Accounting Measures of Operating Performance Outcomes for Australian Mergers. Journal of Applied Accounting, 9(3), 168-180.

Lin, B., \& et. al., (2006). Mergers And Acquisitions As A Human Resource Strategy: Evidence From Us Banking Firms. International Journal of Manpower, 27(2), 126142.

Liu, X., \& Zhou, H. (2008). The Impact Of Greenfield FDI And Mergers And Acquisitions On Innovation In Chinese High-Tech Industries. Journal of World Business, 43, 352-364. 
Lodorfos, G., \& Boateng, A. (2006). The Role Of Culture In The Merger And Acquisition Process: Evidence From The European Chemical Industry. Management Decision, 44(10), 1405-1421.

Mahesh, R., \& Prasad, D. (2012). Post Merger And Acquisition Financial Performance Analysis: A Case Study Of Select Indian Airline Companies. International Journal of Engineering and Management Sciences, 3(3), 362-369.

Majumdar, S., \& et. al., (2007). Quest For Efficiency: Assessing The Impact Of Mergers On Performance In The U. S. Telecommunications Industry. Working Paper Series, 2-58. Retrieved from http://www.univie.ac.at/RNIC/papers/Majumdar_mergerstechprogress.pdf 2015 Jan 31.

Malhotra, S., \& Zhu, P. (2006). Shareholder Benefits And Firm Performance: An Empirical Analysis Of International Acquisitions By Firms From A Developing Economy. Working Paper Series, 1-22.

Mallikarjunappa, T., \& Nayak, P. (2013). A Study of Wealth Effects of Takeover Announcements in India on Target Company Shareholders. Vikalpa, 38(3), 2349.

Mantravadi, P., \& Reddy, A.V. (2008). Post-Merger Performance of Acquiring Firms from Different Industries in India. International Research Journal of Finance and Economics, 22, 193-204.

Mantravadi, P., \& Reddy, A. (2008). Relative Size in Mergers and Operating Performance: Indian Experience. Working Paper Series, 42(39),

Marfo, E.O., \& et. al., (2013). Mergers and Acquisitions: The Performance of the Acquiring Firm-Empirical Study of Cheverontexaco. Canadian Social Science, 9(5), 176-187.

Martynova, M., \& et. al., (2007). The Long-Term Operating Performance Of European Acquisitions. Center Discussion Paper, Tilburg: Finance, 1-40.

McDonald, J., \& et. al., (2005). Planning For A Successful Merger Or Acquisition: Lessons From An Australian Study.Journal of Global Business and Technology, 1(2), 1-11.

Mehrotra, V., \& et. al., (2008). Impact Of Japanese Mergers On Shareholder Wealth: An Analysis Of Bidder And Target Companies. Social Science Research Network Working Paper Series, 1-22.

Meyer, K.E., \& Tran, Y.T.T. (2006). Market Penetration and Acquisition Strategies for Emerging Economies. Long Range Planning, 39(2), 177-197.

Mitleton, K.E. (2006). Co-Evolutionary Integration: The Co-Creation Of New Organisational Form Following Merger And Acquisition. Emergence, 8(2), 36-47.

Mohibullah, (2009). Impact of Culture on M\&As: A Theoretical Framework. International Review of Business Research Papers, 5(1), 255-264.

Mylonakis, J. (2006). The Impact Of Banks' Mergers And Acquisitions On Their Staff Employment And Effectiveness. International Research Journal of Finance and Economics, 3, Proceedings Of The International Online Conference On Business And Management (IOCBM).

Olalekan, O.A.O. (2012). An Analysis of the Impact of Mergers and Acquisitions on Commercial Banks Performance in Nigeria. Research Journal of Finance and Accounting, 3(7), 91-101.

Oduro, I.M., \& Agyei, S.K. (2013). Mergers And Acquisition and Firm Performance: Evidence from the Ghana Stock Exchange. Research Journal of Finance and Accounting, 4(7), 99-107. 
Phillips, G.M., \& Zhdanov, A. (2012). R\&D and the Incentives from Merger and Acquisition Activity. Review of Financial Studies, 26(1), 34-78.

Post, D.J. (2006). Examining Merger And Acquisition Foreign Direct Investment In The United States: Do High Purchase Prices Drive Low Return. Stanford University Department of Economics, 1-40.

Ramakrishnan, K. (2010). Redistribution Of Wealth On Merger Announcements In India. Management Research Review,33(8), 798-810.

Ramakrishnan, R. (2012). Mergers \& Acquisitions In India, The Long-Term PostMerger Performance Of Firms And The Strategic Factors Leading To M\&A Success. Retrieved from http://www.docstoc.com/docs/32303745/Mergersacquisitions-in-India-the-long-term-post-merger

Rani, N., \& et. al., (2011). Impact Of Mergers And Acquisitions On Shareholders' Wealth In Short-Run: An Empirical Study Of Indian Pharmaceutical Industry. International Journal Of Global Business And Competitiveness, 6(1), 40-52.

Ravichandran, , \& et. al., (2010). Market Based Mergers in Indian Banking Institutions. International Research Journal of Finance and Economics, 37, 3039.

Richey, (., \& et. al., (2007). Market Growth Through Mergers And Acquisitions: The Role Of The Relationship Marketing Manager In Sustaining Performance. Industrial Marketing Management, 37, 394-406.

Rizvi, Y. (2011). Human Capital Development Role Of Human Resource (HR) During Mergers And Acquisitions. African Journal of Business Management, 5(2), 261268.

Rogan, M., \& Sorenson, O. (2014). Picking a (Poor) Partner: A Relational Perspective on Acquisitions. Administrative Science Quarterly, 59, 301-329.

Rottig, D., \& et. al., (2014). The Impact of Culture on Mergers and Acquisitions: A Third of a Century of Research. In C.L. Cooper \& S. Finkelstein (Eds.), Advances in Mergers and Acquisitions. (pp. 135-172). Emerald Group Publishing Limited. 12.

Saboo, S., \& Gopi, S. (2009). Comparison Of Post-Merger Performance Of Acquiring Firms (India) Involved In Domestic And Cross-Border Acquisitions. Paper No. 19274 on 25.12.2014. Retrieved from http://mpra.ub.unimuenchen.de/19274/MPRA

Salame, R. (2006). Why Do Mergers Fail?, What Can Be Done To Improve Their Chances Of Success. Retrieved from http://www.scribd.com/doc/109250180/Why-Do-Mergers-Fail\#scribd 2013 Dec 12.

Saundersa, M.N.K., \& et. al., (2009). The Management Of Post-Merger Cultural Integration: Implications From The Hotel Industry. The Service Industries Journal, 29(10), 1359-1375.

Savor, P., \& Lu, Q. (2009). Do Stock Mergers Create Value for Acquirers. Journal of Finance, 64, 1069-1097.

Schein, E.H. (1990). Organizational Culture. American Psychologist Association, 45(2), 109-119.

Schraeder, M., \& Self, D. (2003). Enhancing the Success of Mergers and Acquisitions: An Organizational Culture Perspective. Management Decision, 41(5), 511-522.

Selcuk, E.A., \& Kiymaz, H. (2013). The Impact of Diversifying Acquisitions on Shareholders' Wealth. Retrieved from http://www.aabri.com/NO2013Manuscripts/NO13074.pdf 2011 Jan 13. 
Shook, L.V., \& Roth, G. (2011). Downsizings, Mergers, And Acquisitions: Perspectives Of Human Resource Development Practitioners. Journal of European Industrial Training, 35(2), 135-153.

Siegel, D.S., \& et. al., (2005). Ownership Change, Productivity, and Human Capital: New Evidence from Matched Employer-Employee Data. In Producer Dynamics: New Evidence from Micro Data. (pp. 397-442). Bethesda.

Siegel, D.S., \& Simons, K.L. (2006). Assessing the Effects of Mergers and Acquisitions on Firm Performance, Plant Productivity, and Workers: New Evidence from Matched Employer-Employee Data. In: Proceedings of the Wharton Conference on Careers, the National Bureau of Economic Research, Atlanta.

Siegel, D.S., \& Simons, K.L. (2008). Evaluating the Effects of Mergers and Acquisitions on Employees. In Evidence from Matched Employer-Employee Data" Wharton Conference on Careers and Career Transitions: New Evidence for a New Economy. Philadelphia.

Sinha, N., \& et. al., (2010). Measuring Post Merger and Acquisition Performance: An Investigation of Select Financial Sector Organizations in India. International Journal of Economics and Finance, 2(4), 190-200.

Sinha, P., \& Gupta, S. (2011). Mergers And Acquisitions: A Pre-Post Analysis For The Indian Financial Services Sector. (pp. 2-36). Retrieved from http://mpra.ub.unimuenchen.de/31253/1/MPRA_paper_31253.pdf 2013 Nov 12.

Sony, K., \& et. al., (2009). Voluntary Amalgamations in Indian Banking Sector: Valuation Practices and Adequacy of Swap Ratios. Retrieved from http://Papers.Ssrn.Com/Sol3/Papers.Cfm?Abstract_ld=1653698 2014 Oct 14.

Srivassan, R., \& et. al., (2009). Merger and Acquisition in the Indian Banking SectorStrategic and Financial Implications. IIMB Management Review, Retrieved from http://Tejas-limb.Org/Articles/01.Php 2014 Oct 14.

Stunda, R. (2014). The Market Impact of Mergers and Acquisitions on Acquiring Firms in the US. Journal of Accounting and Taxation, 6(2), 30-37.

Syazliana, A.M.I., \& et al., (2015). Corporate Cultures Integration and Organizational Performance: A Conceptual Model on the Performance of Acquiring Companies. Procedia - Social and Behavioral Sciences, 172, 591-595.

Tambi, M.K. (2005). Impact Of Mergers And Amalgamation On The Performance Of Indian Companies. Econ WPA Finance, (0506007).

Uchendu, O.A. (2005). Banking Sector Reforms And Bank Consolidation: The Malaysian Experience. Bullion, Central Bank Of Nigeria, Abuja, 29(2),

Vanitha, S., \& Selvam, M. (2007). Financial Performance Of Indian Manufacturing Company During Pre And Post Mergers. International Research Journal of Finance and Economics, 12, 7-35.

Vaziri, M.T. (2011). Stock Price Reaction to Acquisitions in Banking Sector: An Empirical Analysis on Selected Asia Pacific Countries. The Journal of American Academy of Business, 17(1), 51-61.

Waddock, , \& Graves, (2006). The Impact of Publishing. Journal of Corporate Citizenship, 22, 1-20.

Wang, , \& et. al., (2012). Business Mergers And Acquisitions And The Risk Of Mental Disorders: A Population-Based Study. Occupational And Environmental Medicine, 69(8), 569-573.

Walter, C.N., \& Uche, U. (2005). New Capitalization For Banks: Implication For The Nigerian Economy. Adamawa State University Business Journal, 1(1), 
Ghosh S., Dutta S.: Mergers and Acquisitions: A Comparative Review of Literature

Weber, Y., \& Tarba, S.Y. (2012). Mergers And Acquisitions Process: The Use Of Corporate Culture Analysis. Cross Cultural Management. An International Journal, 19(3), 288-303.

Wickramasinghea, , \& et. al., (2009). People Management In M\&As In Sri Lanka: Employee Perceptions. The International Journal of Human Resource Management, 20(3), 694-715.

Wong, , \& et. al., (2009). The Effects of Merger and Acquisition Announcements on the Security Prices of Bidding Firms and Target Firms in Asia. International Journal of Economics and Finance, 1(2), 274-283.

Yang, H., \& et. al., (2011). Behind Acquisitions Of Alliance Partners: Exploratory Learning And Network Embeddedness.Academy of Management Journal, 54(5), 1069-1080.

Yuce, A., \& Ng, A. (2005). Effects of Private and Public Canadian Mergers. Canadian Journal of Administrative Sciences,22(2), 111-124.

Zaheer, A., \& et. al., (2013). Synergy Sources, Target Autonomy, And Integration In Acquisitions. Journal Of Management,39(3), 604-632. 